\title{
Javanese People's Acceptance of Arabic Calligraphy as Home Decoration
}

\author{
Retno Purnama Irawati $^{1 *}$, Singgih Kuswardono ${ }^{2}$, Ahmad Miftahuddin $^{3}$, Siminto $^{4}$ \\ ${ }^{1}$ Universitas Negeri Semarang, Semarang, Indonesia. Email: rp.irawati@mail.unnes.ac.id \\ ${ }^{2}$ Universitas Negeri Semarang, Semarang, Indonesia. Email: singgihkuswardono@mail.unnes.ac.id \\ ${ }^{3}$ Universitas Negeri Semarang, Semarang, Indonesia. Email: ahmadmiftahuddin_82@mail.unnes.ac.id \\ ${ }^{4}$ Institut Agama Islam Negeri Palangka Raya, Indonesia. Email: siminto@iain-palangkaraya.ac.id
}

Corresponding Email: rp.irawati@mail.unnes.ac.id

Article History: Received: 10 November 2020; Revised 12 January 2021 Accepted: 27 January 2021; Published online: 5 April 2021

\begin{abstract}
The interweaving of Arabic calligraphy letters is a combination of artistic art. Arabic calligraphy is giving rise to aspects of visual beauty that can be enjoyed and created a sense of joy. It can encourage people to get closer to Allah, love for goodness, nobility, and so on. Arabic calligraphy is infused into the hearts of those who see, by the meaning of the text. Apart from being a form of reception for one of the verses in the Koran, namely in the verse al-Kursī, calligraphy has developed in various forms and includes various functions and fields that are indirectly connected with the text of the Quran. Starting from the context of the Koran alone, and the spiritual substance of the Koran that continues to live in all aspects of traditional Islamic calligraphy. Calligraphy is also the choice of Muslims in Central Java to decorate the walls of their homes. The choice of calligraphy to decorate the walls of the house is based on various reasons, ranging from aesthetic, religious, to magical reasons. This research was conducted to conduct a more in-depth analysis of the Central Javanese people's reception of Arabic calligraphy as a home decoration and to analyze the reasons for choosing Arabic calligraphy as a home wall decoration for the Muslim community of Central Java. This research is qualitative research with a phenomenological research design. The data collection technique is done using documentation techniques, interviews, and distributing questionnaires. The questionnaire was created using a combination open and closed question model for all groups of respondents. Data analysis in this study used statistical calculations on respondents' answers to the questionnaire, which were analyzed qualitatively. The research subjects were the Muslim community in Central Java, totaling 164 adults. When viewed from the gender of the respondents, 91 people (or $55 \%$ of respondents) were male, and 73 people (or $45 \%$ of respondents) were female. Calligraphy is a medium for conveying religious messages through language. The language chosen is a significant or straightforward language that is easy to understand or understand in sentences. The writing style displays beautiful shapes so that the type of style that is elastic or flexible and easy to create is chosen to make a beautiful impression, namely the tsutust and naskhiy types. The artistic expression that most strongly displays the substance of calligraphy is the traditional expression that has been chosen as an artistic expression. Figural and expressionist forms of expression were chosen because of their role in providing new nuances of free calligraphic expression
\end{abstract}

Keywords: Arabic calligraphy; receptions; Muslim community; home decoration

\section{Introduction}

Calligraphy in various literatures is often understood as the art of beautiful writing, that is writing in accordance with the rules or rules of writing, or painting letters intended as decorative writing. In Indonesia, the development of calligraphy is not limited to certain types of writing, there are Arabic, Chinese, Javanese, Japanese, and others. Each has its own characteristics and characteristics in accordance with its history and culture. At least every type of calligraphy owned by people from various regions has a function of beauty and becomes a means of appearing for metaphysical messages that are written in their culture (M. F. Mujahidin, 2016). 
Islamic calligraphy has the historical roots of the beautiful writing tradition of the Arabs, as the land from which calligraphy was born. The tradition of beautiful writing is called khat as a manifestation of the meaning of the word calligraphy, which comes from the word calligraphia which means beautiful writing (Nuralia, 2017)(Ambary, 1991). Arabic calligraphy originating from the Qur'an besides having an artistic form, also has a noble meaning, which is a depiction of the word of God. Arabic calligraphy as a work of art is a mixture of verses quoted in the Qur'an with a visual form that is displayed so that it becomes a work of art. Visual beauty (explicit meaning) behind the artwork also contains non-visual meaning (implied meaning). The meaning is the spearhead in artistic expression, and the visual form it presents is a copy or representation that is never perfect and complete (Rispul, 2012). Arabic calligraphy has maintained itself as a form of enduring craft with subjective relations with Arabic culture and Islamic heritage. Arabic characters are one of the most important visual arts in the architectural heritage elements created by Muslim artists. The implementation of Islamic teachings that love beauty, is also a form of creative design. It integrates cultural language with geometry because letters can be drawn and transformed in various ways to create different motifs (Hussein, 2017).

Interwoven Arabic calligraphy letters are a blend of artistic art. Arabic calligraphy gives rise to aspects of visual beauty that can be enjoyed and created pleasure. Arabic calligraphy encouraging people to draw closer to Allah. Arabic calligraphy also fosters love for kindness, nobility and so on, which is absorbed into the heart of the beholder, by the meaning of the interwoven text (Rispul, 2012). The art of calligraphy is not merely an expression of art in the beauty of writing. However, more than that, calligraphy is an important part of the expression of Godliness inspired by Al Quran. Quran influences the calligraphy of the most important art form in Islamic culture. Its influence and superiority is found in every Muslim world, in every century in Islamic history, in every imaginable art object. Among all categories of Islamic art, calligraphy is the most common and most important and most appreciated and respected by Muslims (Jinan, 2010).

The flexibility of the Arabic script allows the development of Islamic calligraphy with various functions. The flexibility of the Arabic script allowed the development of Islamic calligraphy with various functions. In classical Indonesian-Islamic art, Arabic calligraphy does not play many roles in classical mosque decoration. In several Islamic kingdoms outside Java, there were mosques that imitated mosques from outside Indonesia with Arabic calligraphy decorations. Mosques such as those erected in Aceh and Medan display rich Arabic calligraphy decorations in keeping with the mosque style similar to the Persian or Indian style. Arabic calligraphy in Indonesia mostly acts as an ornamental motif rather than developing the aesthetic value of the art of writing itself (Sucitra, 2015).

The art of Arabic calligraphy has developed and progressed along with the revelation of Al Quran and the expanding development of Islam. In general, the reception (acceptance attitude) of Muslims towards Al Quran is divided into three: hermeneutical receptions, socio-cultural receptions and aesthetic receptions. The first type of reception shows more of an effort to understand the contents of Al Quran, which is mostly done by translating and interpreting the verses of $\mathrm{Al}$ Quran. This is done with the aim of enabling $\mathrm{Al}$ Quran to become a life guide for Muslims. While the second and third types of receptions show how Muslims function Al Quran socially and culturally for certain "interests" which sometimes have no direct connection with the meaning of the text of $\mathrm{Al}$ Quran. (Baidhowi, 2007)(Jinan, 2010).

$\mathrm{Al}$-Quran and also Hadith have a very big influence on the existence of Arabic Calligraphy. This makes calligraphy has visual strength not only felt by the eye, but the heart and the feeling also enjoy it. The flexible and artistic character of Calligraphy makes it easy to exploit aesthetically. This has led to the development of Arabic calligraphy, which was originally only for copying versus of Al Quran, to develop rapidly, from media, techniques, applications to functions. Until now, Arabic calligraphy in its application and function has begun to enter into interior design. The need for interior furnishings is not just to fulfill a functional aspect, but also to consider the aesthetic value in creating or presenting comfort both physically and spiritually (Tesnawan, 2014).

Al-Quran has always provided motivation for humans throughout the ages (Jalil, 2013). The interaction between the reader and Al Quran causes an action or reaction in social life (or reception of Al Quran) (Esack, 2005). The reception can take many form. Mattson said in his research that Al Quran has profoundly affected the lives of Muslims. This shows that in every behavior, tradition and even culture of Muslims to this day have received a touch from Al Quran (Rahman, 2018).

Calligraphy is often found, one of which is calligraphy that reads one of the verses in Al Quran, namely the verse al-Kursī. Ali Ahmad Abdul Al-Tahțawi mentioned some of the virtues of the verse al-Kursī, including (1) 
as the most glorious verse in Al Quran, (2) in the al-Kursī verse there are the names of Allah the Great, (3) if the alKursī verse read after the Fardlu prayer, it will be under Allah's guard until the prayer afterwards, (4) If reading the al-Kursī verse after praying nothing will prevent him from entering heaven unless he dies, and (5) reading the verse al-Kursī can expel devil (At-Tahtawi, 2004). The reception of the verse al-Kursī is dominated by the socio-cultural reception. It can be seen how the meaning of the people mentioned in the literature of the al-Kursi verse. This meaning occupies a very worldly function, such as so that one's wish is granted, physical and mental security, and as a treatment. (Rahman, 2018).

The calligraphy verse of al-Kursī is a form of reception for one of the verses in Al Quran. Calligraphy has developed in various forms, covering various functions and fields that are indirectly connected with the text of $\mathrm{Al}$ Quran. There is something related in principle between calligraphy. Principles that originate from the context of Al Quran alone, and the spiritual substance of Al Quran that continues to live in all aspects of traditional Islamic calligraphy. Martin Lings, a devotee of the holy art of Islam, says calligraphy helps Muslims penetrate the divine space. Calligraphy permeates a Divine presence that matches the spiritual capacity of each person (Lings, 1976)(Jinan, 2010).

The presence of Arabic calligraphy as the most important aspect of Islamic culture can generally be recognized as fostering various other alternatives to the fulfillment or need of artist expression. This kind of relationship can also be interpreted that the magnitude of the artist's intention in looking for beauty values so that anything that can evoke aesthetic experiences can be expressed through Arabic calligraphy (Rispul, 2012). The presence of calligraphy which cannot be separated from the presence of Islam, calligraphy is implemented in various forms. The entry of Islam has changed the contents of the amulet visually. Amulets that originally speak ancient Javanese, or ancient Sundanese and contain spells. The mantra is then converted into Arabic script which contains prayers or fragments of verses from the Quran and Arabic script (Raden, Andrijanto, \& Sukarwo, 2019).

The use of Arabic script amulets written in beautiful writing such as calligraphy, is believed by the public to be something sacred and has high spiritual value. People still have the belief that a piece of the Quran verse written on a piece of paper can give strength to the wearer. Even though it is closely related to magical elements, some of the practices of using amulets in society show a connection with belief in Islam. This can be seen in the use of verses from Al Quran in objects that are considered amulets (Raden et al., 2019)(A. Mujahidin, 2017).

The use of Quranic verses as a source of magical power in the Muslim world is also recognized by Bowen who has researched the Gayo community. Bowen argues that the holy book of Al Quran is understood as a powerful utterance or sentence (having magic power). The Muslim community in Isak Gayo studies and reads Al Quran not only to gain reward and knowledge, but also the supernatural power that comes from it. They believe, by reading certain verses that are considered to have magic power, the reader will get God's gift in the form of certain magic effects or powers as contained in these specific verses. This condition, according to Bowen, does not only occur in the Isak Gayo Muslim community, but also Muslim communities in Sumatra, Pakistan, or Egypt. (Bowen, 1993)(Humaeni, 2014).

Al Quran that is believed to have magic power. Al Quran is an antidote to the arrival of occult disturbances, as well as the arrival of fortune is an understanding that is believed by the community from generation to generation. Calligraphy depicting pieces of the holy Quran verses in the Muslim community of Central Java is the main choice for decorating the walls of their homes. The choice of calligraphy to decorate the walls of the house are based on various reasons, ranging from aesthetic reasons, religious reasons, to reasons that are magical. This research was conducted to conduct a more in-depth analysis of the Central Javanese people's reception of Arabic calligraphy as a home decoration and to analyze the reasons for choosing Arabic calligraphy as a home wall decoration for the Muslim community of Central Java.

\section{Literature Review}

Dr. Laila Al-Qahtani and Dr. Salwa A. Megahed researched the relationship between Arabic script and furniture design. The research also reveals the characteristics of the Arabic script and the possibility to adapt the unique features of the Arabic script to make it into modern furniture designs. Researchers try to adapt the Arabic script's unique characteristics to be adapted into a particular furniture style that is flexible and sustainable. This study also examines much literature to identify and classify various uses of Arabic calligraphy in modern and sustainable furniture designs. The researcher used three-dimensional modeling software to analyze multiple Arabic calligraphy forms and chose the most flexible Arabic script in furniture design. Analysis of the shapes and 
proportions of different Arabic calligraphy characters simulates the possibility of adapting Arabic calligraphy with flexible and sustainable furniture designs (Al-Qahtani \& Megahed, 2015).

Mayyadah Fahmi Hussein, through his research, found that interior design in the Arab world needs to be produced and rearranged so that it can be adapted to human needs. Many internal and external facades in Arabic regional buildings always use Arabic calligraphy as the main feature of decoration. Arabic calligraphy reflecting the strength of the letter in minimizing the impact on a massive scale. Arabic calligraphy is still used conventionally. Arabic calligraphy has not been used in interior design and is only an informative tool that ignores aesthetic considerations. On the other hand, calligraphy has unique characteristics. The formation of Arabic calligraphy letters is related to art and design, although so far, Arabic calligraphy has not been used in interior design as a form of three-dimensional furniture or indoor space arrangements. This study aims to analyze the integration of the Arabic cultural context in contemporary interior design. This is done to look for new creative ideas to rearrange modern interior design with an innovative approach. This study focuses on (1) the identity of architectural interior design through Arabic letters, (2) Arabic calligraphy communication, in interior design, without reading activities, and (3) interior design techniques not only in elevation and furniture but also in structural design (Hussein, 2017).

The difference between this article and previous research is in the unit of analysis. Calligraphy in both studies tends to embody contemporary expressions and is used in various functions. Calligraphy, in this study, does not appear to have a function as a mere artistic expression. The function of calligraphy in Javanese society has shifted from an aesthetic function to a religious function and a magical function. The next difference is that calligraphy in previous studies is used for interior design and modern furniture. Meanwhile, calligraphy for Javanese people, in this study, is used for writing prayers, motivation, and amulets.

\section{Research Methods}

This research is qualitative research with a phenomenological research design. Phenomenology that will be applied in this research refers to the reader-response theory, which emphasizes the sensing and perceptual processes of text, the study of phenomena, or the study of objects as they appear in people's experiences (or the way people experience and collect meaning) and things (Lobo, 2013)(Shi, 2013). The research subjects were the Muslim community in Central Java, totaling 164 adults. When viewed from the gender of the respondents, 91 people (or $55 \%$ of respondents) were male, and 73 people (or $45 \%$ of respondents) were female. The percentage of the respondent's occupation can be seen in the following diagram.

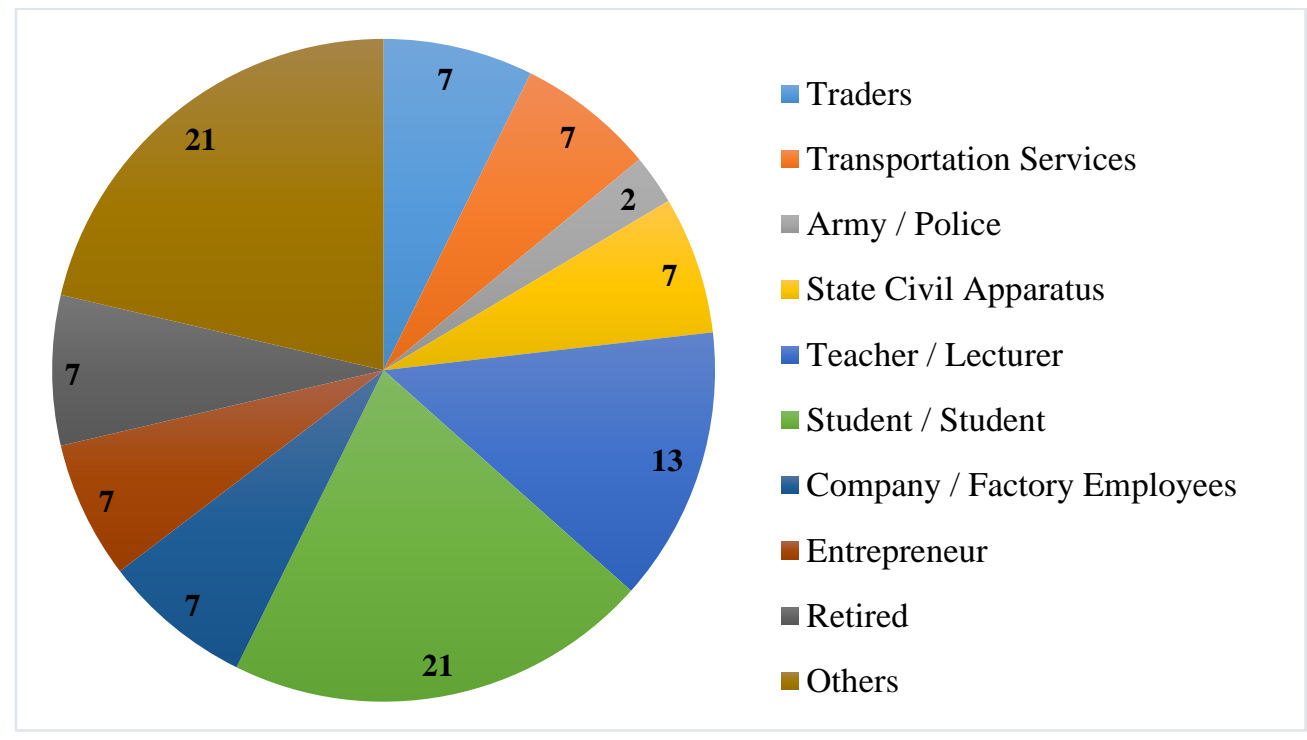

The data collection technique is done using documentation techniques, interviews, and distributing questionnaires. The questionnaire was created using a combination open and closed question model for all groups of respondents. Data analysis in this study used statistical calculations on respondents' answers to the questionnaire, which were analyzed qualitatively. Three data analysis processes were also carried out, namely: data reduction, data presentation, and conclusion/verification. 


\section{Result and Discussion}

Reception is not just a process of receiving and responding to something, but creating dynamic meanings between readers' interactions with the text. The reception process is an embodiment of intellectual awareness. This awareness arises from the reflection, interaction, and the process of translating and understanding the reader. What has been received by the reader, restructured, and concreted in mind. The assumption that has been constructed forms a kind of capture space so that the materials obtained become a kind of contour for an individual world (Jannah, 2017). The acceptance of Central Java people for Arabic calligraphy is illustrated in various responses regarding the meaning, form, function of Arabic calligraphy, and the reasons for choosing Arabic calligraphy as a home wall decoration.

The Arabic calligraphy owned by the respondents made of various materials. Cloth, canvas, wood and bamboo, and glass are the most widely used media for making Arabic calligraphy as a display of home decor. These four materials are most commonly found and created in various types of goods, including Arabic calligraphy. Some other materials used as materials for making Arabic calligraphy can be seen in table one below.

Table 1. Calligraphy Materials

\begin{tabular}{|l|r|r|}
\hline \multicolumn{1}{|c|}{ Calligraphy Materials } & Frequency & Percentage \\
\hline Fabric (stamp / embroidery) & 20 & 12 \\
\hline Canvas cloth & 20 & 12 \\
\hline Wood and bamboo & 20 & 12 \\
\hline Glass & 20 & 12 \\
\hline Paper & 19 & 12 \\
\hline Ceramics & 12 & 7 \\
\hline Cement / gypsum & 12 & 7 \\
\hline Aluminum & 12 & 7 \\
\hline Brass & 11 & 7 \\
\hline Animal skins and shells & 6 & 4 \\
\hline Stereofoam & 4 & 2 \\
\hline Natural stone & 2 & 1 \\
\hline Whole grains & 2 & 1 \\
\hline Sticker & 2 & 1 \\
\hline Plastic & 2 & 1 \\
\hline & $\mathbf{1 6 4}$ & $\mathbf{1 0 0}$ \\
\hline
\end{tabular}

Brass is very easy to form into many forms, is a good conductor of heat, and is generally resistant to saltwater corrosion. Because of these properties, brass is mostly used to make pipes, tubes, screws, radiators, musical instruments, marine applications, and cartridge casings for firearms (Santoso, 2015). Brass is also used as a material for making Arabic calligraphy. Brass calligraphy crafts are done by craftsmen manually. The process starts from cutting brass plates, forming calligraphy reliefs to the finishing process done very carefully, and paying close attention to calligraphy details. Calligraphy made of brass has high artistic value, has a unique and natural design, making anyone who sees it will be amazed and reminded of Allah. Calligraphy made of brass has many advantages, such as (1) making the room look elegant and luxurious with its yellow luster; (2) calligraphy made of brass is much more durable than calligraphy that is painted with oil and print; (3) the high value of calligraphy art is made of brass due to the complicated manufacturing process; (4) it can be installed indoors and outdoors; (5) the color that is not easily corroded; (6) it is resistant to heat and rain; ang (7) if it is dirty, it is enough to clean it with a clean cloth that has become shiny again.

When viewed from the general meaning contained in calligraphic expressions, based on existing data, messages on calligraphy expressions can be grouped into several types of messages, namely (1) religious messages, (2) congratulations, (3) proverbs, (4) expressions free, and (5) name. 
The form or structure of calligraphy expressions can be grouped based on their language units or grammatical categories as follows, starting from the largest units, namely discourses, sentences, phrases, and words. Calligraphy that displays a full letter such as letter al Ikhlas, letter al Falaq, letter al Nas, letter al Fatihah can be classified as a discourse-shaped calligraphy expression. In addition, the calligraphy expression in the form of a discourse is also found in long verses such as the chair verse. Calligraphic expressions in the form of sentences are expressions that are most often found in calligraphy works, generally writing that raises a short verse or a cut of a verse or a piece of al Hadith is a calligraphy expression in the form of a sentence. Among the calligraphy writings are in the form of phrase units such as the name of the mosque, such as (مسجد السيّدة ، مسجد بيت المعمور) or the name of Islamic holidays (عبد الأضحى المبارك). The most common word categories that are often encountered as an expression of calligraphy are pronunciation (اللها:د) and (محمد).

From samples of Central Javanese calligraphy expressions, the dominant type or style used in calligraphy expressions is Tutsulusiy. There are 39 or $55.71 \%$ of the writing in tsulust style. The characteristic of khat tsulust shows flexibility which makes it easy for the letters to be lengthened or shortened to fit into the existing space or shape. Lined lines and extended vertical lines are standard features of this writing.

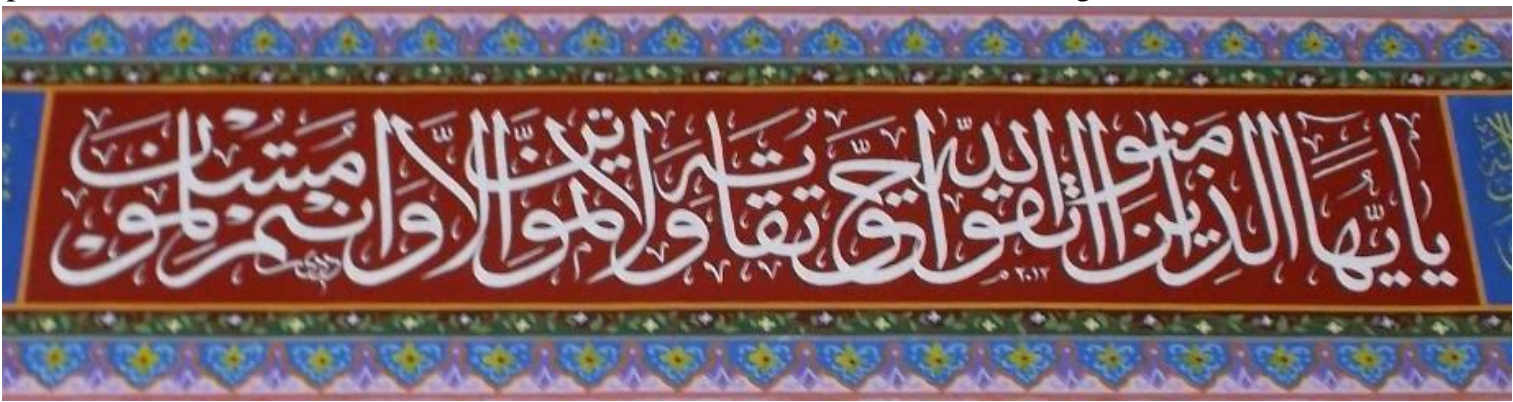

Figure 1. Tsulust-style calligraphy on wall media (graffiti)

Another type or style of calligraphy that is commonly found is naskhiy. There are 17 or $42.50 \%$ naskhiy style writing. Khat naskh is a form of Arabic calligraphy that resembles khat tsuluts, it's just that the shape is simpler or not as complicated as khat tsulust. Khat naskh is generally used according to the name naskh or manuscript, namely writing texts or books. The main characteristic of khat naskh is a cursive form, which is a circular motion. Apart from that it is characterized by its clarity, simplicity, and ease of reading.

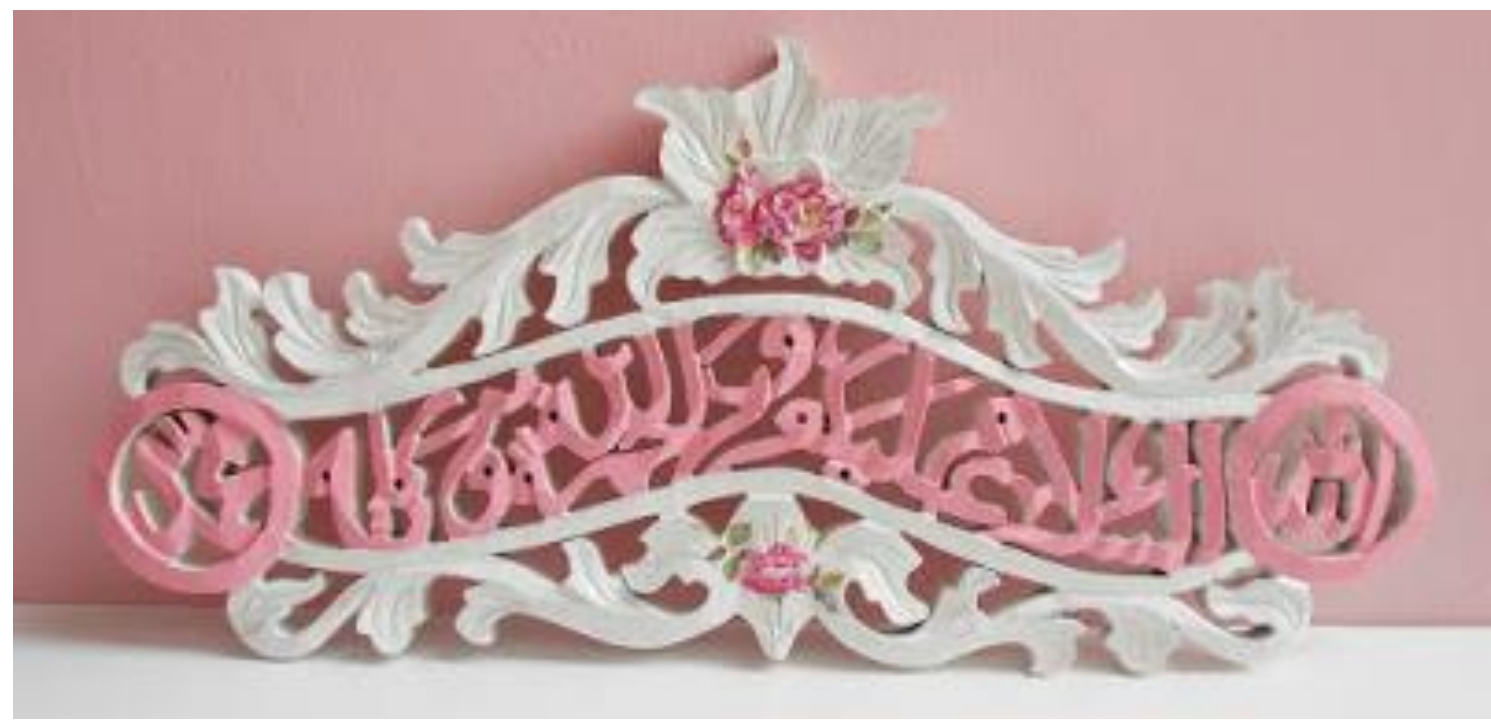

Figure 2. Naskhi-style calligraphy on stone media

A style that is rarely used in calligraphic expressions in the Central Java region is $f a>$ risiy. There are three or $4.28 \%$ of the posts in $f a>$ risiy style. Khat farisiy or khat ta'li $<q$ or khat nasta'li $<q$ is a form of Arabic calligraphy that accentuates the aesthetic element by displaying the strength of letters and eliminating supporting decorations. Khat $f a>$ risiy is characterized by the letters' posture slightly tilted to the right, the letters often have a thickness that 
is not the same as conspicuously, so it takes more than one pen in writing. Besides that, it has a distinctive characteristic is the number of letters that have a flowing horizontal curve and are too extended. Filling in small circles, very fragile and sharp edges of letters, emphasis on flat rather than vertical strokes, and contrasting the lines' width are also other characteristics of $f a>$ risiy typeface.

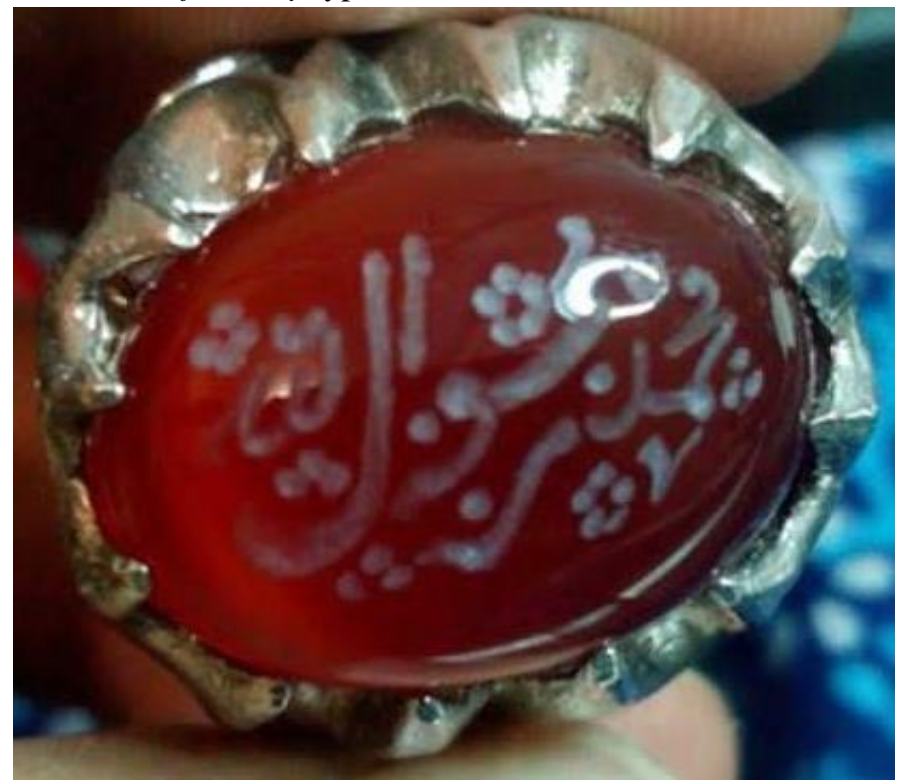

Figure 3. Calligraphy in physical style on agate media

Another style that is rarely used as a form of calligraphy expression in the Central Java region is diwaniy. There are two or $2.85 \%$ diwaniy style writing. Khat diwa $>$ niy is a form of Arabic calligraphy that also accentuates an aesthetic element by displaying curved lines. The characteristic of khat in <wa > niy is flexible arches, the posture is tilted to the left in layers with decorative patterns that show its beauty. Another feature is that the round writing is recognizable by its excessive flowing movements and the gradual elevation and lengthening of the letters at the end of the line.

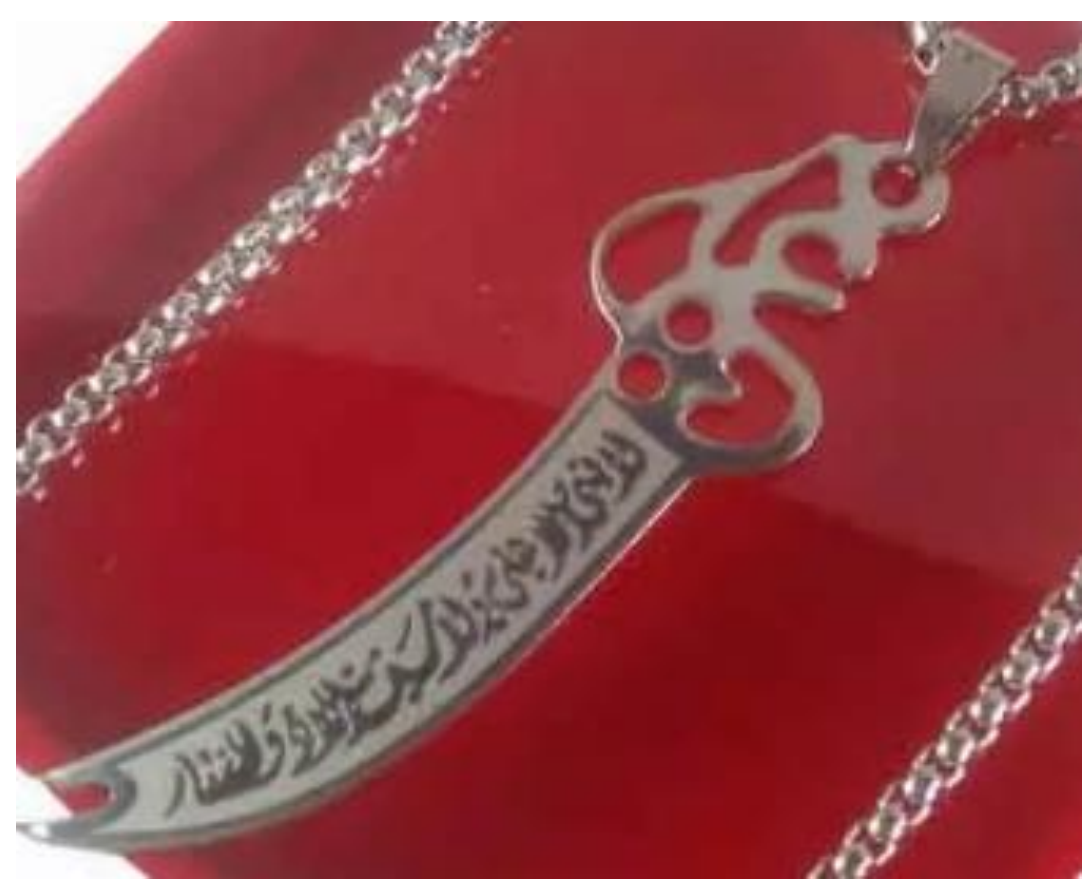

Figure 4. Diwaniy-style calligraphy on mini sword-shaped accessories 
Apart from these styles, there are mixed styles that try to combine several types of calligraphy, such as (1) a combination of diwaniy and naskhiy styles in the expression (الله محمد); (2) a combination of diwaniy, tsulust, and

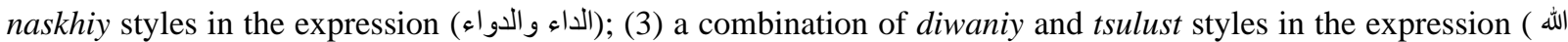
and (اللهمد ، أشهد أن لا إله إلا الله وأنشه أن محمد رسول الله so that their writing styles cannot be grouped. However, there are non-standard forms that are the development of standard formats to appear as contemporary forms, such as the three forms of development of the tsulust style.

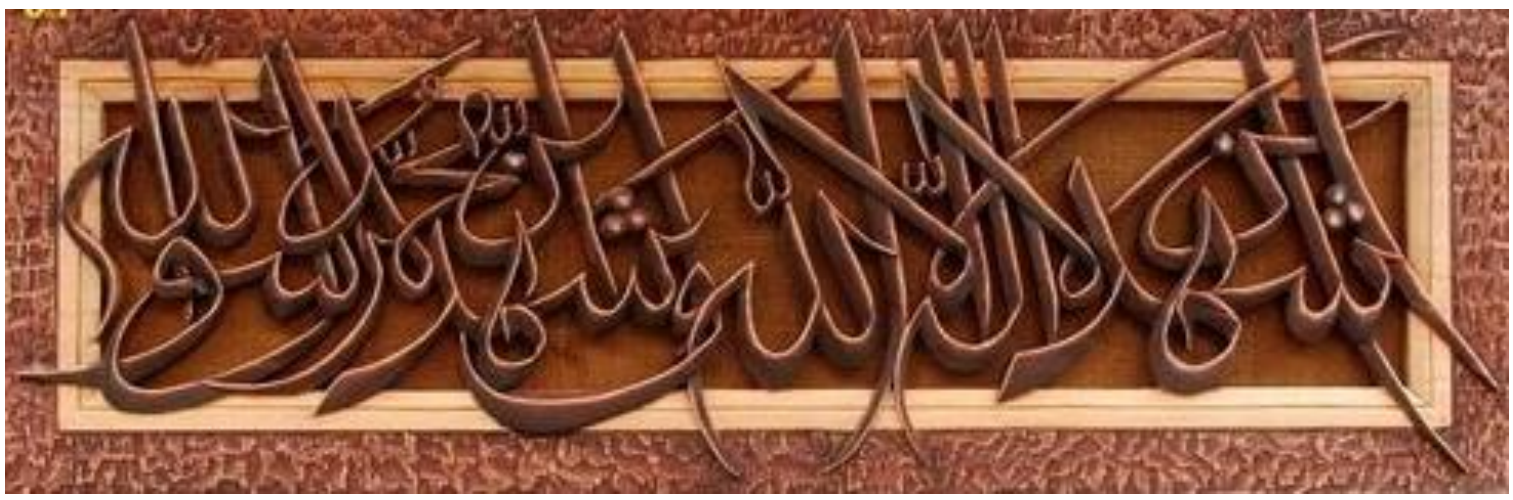

Figure 5. Contemporary non-standard calligraphy, the development of tustust style on wood media

This type of traditional expression is a type of calligraphy art expression widely used by the people of Central Java. From the existing sample, there are 25 or $35.71 \%$ types of traditional calligraphy expressions. Traditional calligraphy is an example of a category that shows harmony with long-established habits and more standard elements in the Islamic tradition. Another type of expression that is just as widely used after traditional expressions is figural calligraphy expression. There are 25 or $35.71 \%$ types of figural calligraphy used by the people of Central Java. In figural calligraphy design, letters can be extended and shortened, stretched and pressed, or made transparently. This is done by lengthening, twisting, and looping or adding or filling, bringing them into harmony with the shapes of no calligraphic, geometric, plant, animal (zoomorphic), or human figures.

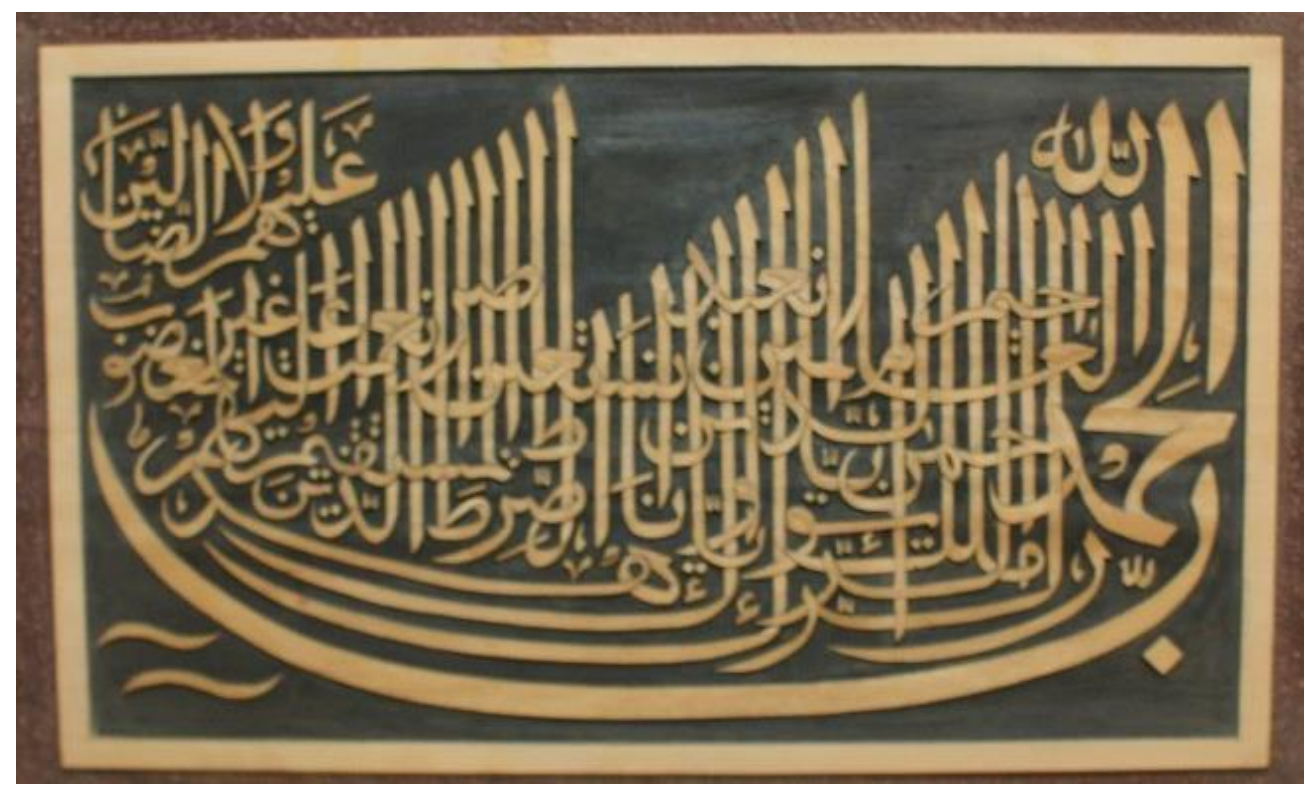

Figure 6. Figural calligraphy of the al Fatihah letter ship on wood media

Expressionist calligraphy ranks next in terms of numbers; namely, there are 13 or $15.57 \%$ expressionist calligraphy types. The term expressionist has been used to classify calligraphy in which elements and exaggerations are prominent. Expressionist art emphasizes human emotions, moods, subjective feelings, and individualistic attention. 


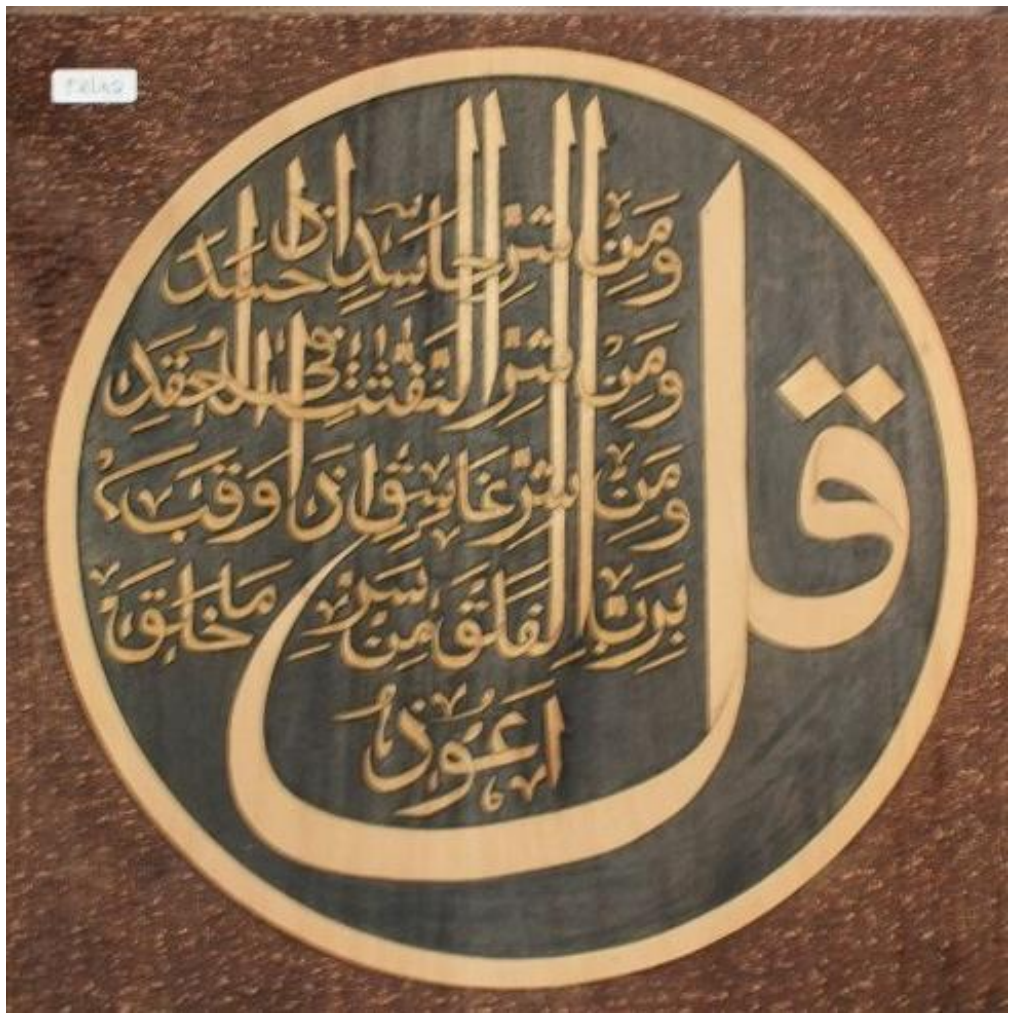

Figure 7. Expressionist calligraphy letter al Falaq on wood media

In addition, there are also 6 or $8.57 \%$ calligraphy expressions of pure abstraction type or fake calligraphy that cannot be read because they are a series of meaningless letters.

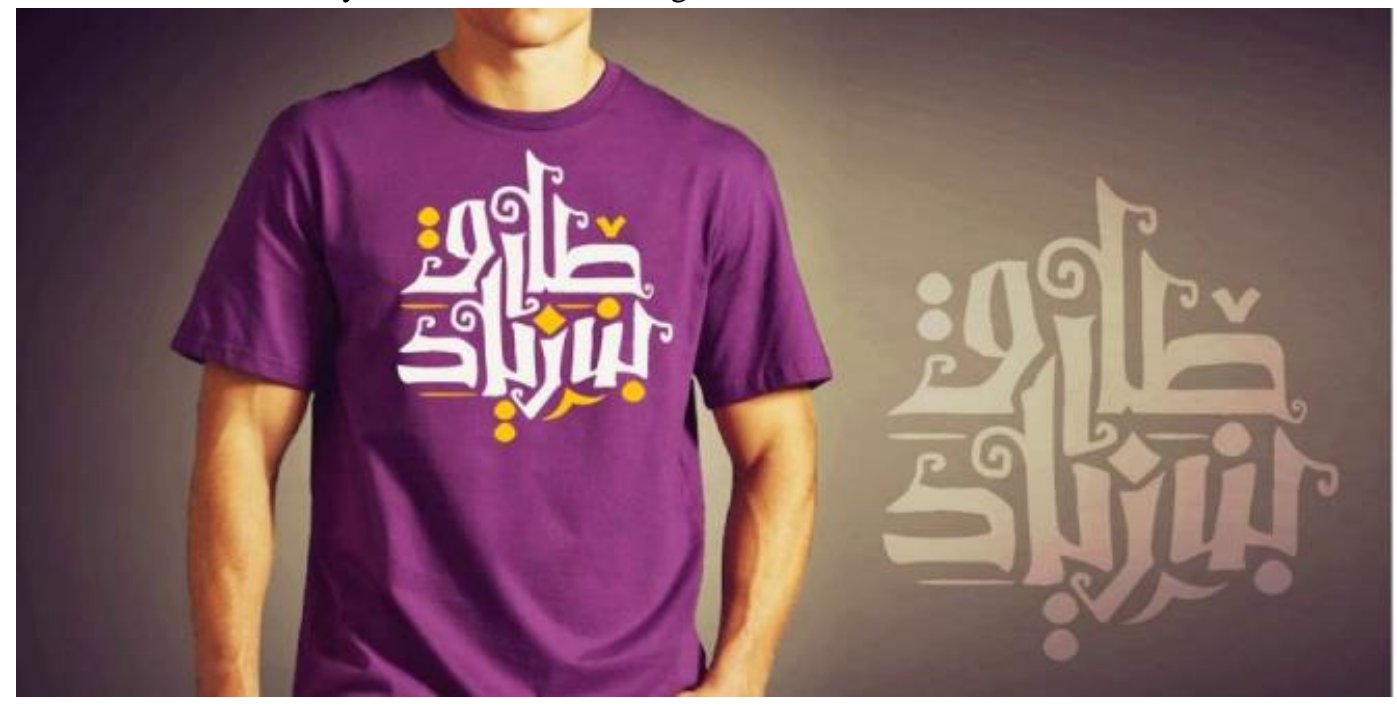

Figure 8. Pure abstraction calligraphy or fake calligraphy on t-shirt media

The smallest amount is symbolic calligraphy, which is 2 or $2.85 \%$. Symbolic calligraphy is calligraphy whose design uses special letters or words to symbolize an idea or a collection of ideas. Symbolic letters are juxtaposed in such a composition with the representation of the object of the relationship in order to convey a certain message. A combination like this only has a purity as an expression of the artist's choices and feelings. 


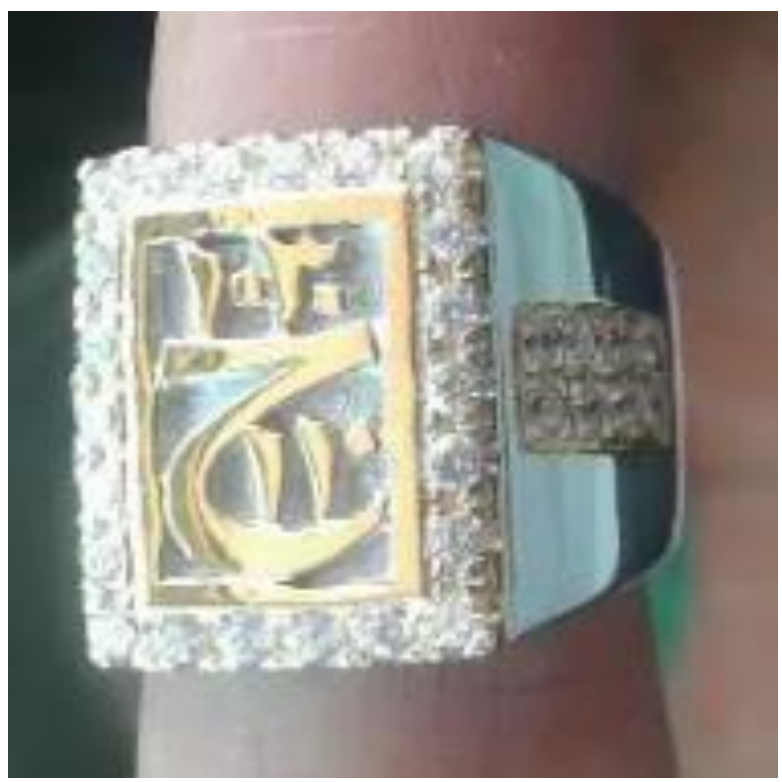

Figure 9. Symbolic calligraphy in the form of numbers (1030 above, 110 below) and letters ( $\tau$ ) on the media for ring accessories.

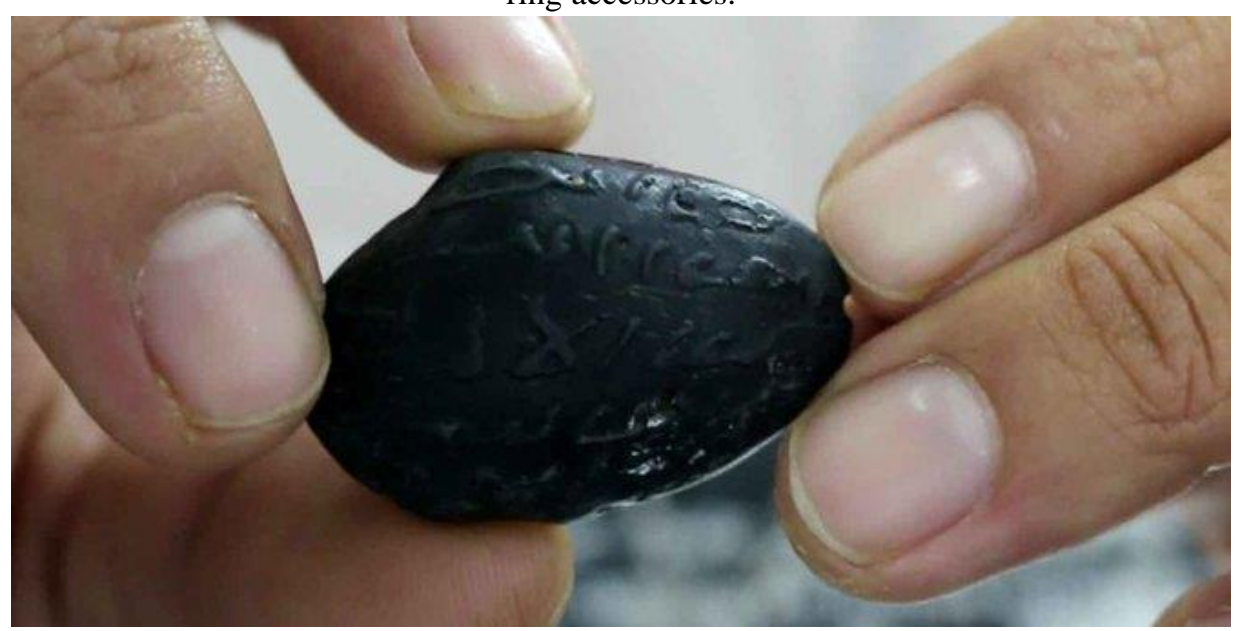

Figure 10. Symbolic calligraphy in the form of three letters $\left({ }^{\prime}\right)$ and $\left({ }^{(}\right)$on stone media

\section{Conclusion}

The types of messages mostly raised by calligraphic expressions originate from the Koran and al Hadith. However, there are also other messages such as proverbs or names but the number is insignificant. The grammatical category or the language unit of calligraphy expression takes the form of a sentence which is generally stated in a letter or letter fragment. However, there is also a calligraphy expression subuah discourse in the form of a full letter or a long verse containing several main points of thought. The most common styles of calligraphy are tsututs and naskhiy. Meanwhile, the most prominent artistic expressions are traditional, figural, and expressionist expressions.

From this research it can be concluded that calligraphy is a medium for conveying religious messages through language. The language chosen is a significant or straightforward language that is easy to understand or understand in sentences. The writing style displays beautiful shapes so that the type of style that is elastic or flexible and easy to create is chosen to make a beautiful impression, namely the tsutust and naskhiy types. The artistic expression that most strongly displays the substance of calligraphy is the traditional expression that has been chosen as an artistic expression. Figural and expressionist forms of expression were chosen because of their role in providing new nuances of free calligraphic expression.

\section{References}

[1]. Al-Qahtani, L., \& Megahed, S. A. (2015). Emerging Trends in Sustainable Furniture Design: An Experimental Study on Arabic Calligraphy. Emirates Journal for Engineering Research, 20(1), 17-26. 
Retrieved from https://eng.uaeu.ac.ae/en/research/journal/ issues/v20/

[2]. Ambary, H. M. (1991). Kaligrafi Islam Indonesia: Dimensi dan Signifikasinya Dari Kajian Arkeologi. Jakarta: Pusat Penelitian Arkeologi Nasional.

[3]. At-Tahtawi, A. A. A. 'Al. (2004). Syarh Ayat al-Kursī: Faḍāiliha wa Khawassiha. Beirut: Dar al-Kutub al-Ilmiyah.

[4]. Baidhowi, A. (2007). Resepsi Estetis terhadap Al-Quran. Esensia: Jurnal Ilmu-Ilmu Ushuluddin, 8. Retrieved from http://ejournal.uin-suka.ac.id/ushuluddin/esensia

[5]. Bowen, J. R. (1993). Muslims through Discourse: Religion and Ritual in Gayo Society. New Jersey: Princeton University Press.

[6]. Esack, F. (2005). The Qur'an: A User's Guide. Retrieved from https://www.goodreads.com/book/show/524422.The_Qur_an

[7]. Humaeni, A. (2014). Kepercayaan Kepada Kekuatan Gaib Dalam Mantra Masyarakat Muslim Banten. El Harakah, 16(1), 51. https://doi.org/10.18860/el.v16i1.2769

[8]. Hussein, M. F. (2017). The Role of Arabic Calligraphy in Forming Modern Interior Design. Modern Applied Science, 11(3), 53. https://doi.org/10.5539/mas.v11n3p53

[9]. Jalil, A. (2013). Sejarah Pembelajaran Al-Qur'an Di Masa Nabi Muhammad Saw. INSANIA : Jurnal Pemikiran Alternatif Kependidikan, 18(1), 1-17. https://doi.org/10.24090/insania.v18i1.1438

[10]. Jannah, I. L. (2017). Resepsi Estetik Terhadap Alquran pada Lukisan Kaligrafi Syaiful Adnan. Nun : Jurnal Studi Alquran Dan Tafsir Di Nusantara, 3(1), 25-59.

[11]. Jinan, M. (2010). Kaligrafi Sebagai Resepsi Estetik Islam. Jurnal Suhuf, 22(2), 142-156. Retrieved from http://journals.ums.ac.id/index.php/suhuf/issue/archive

[12]. Lings, M. (1976). The Quranic Art of Calligraphy and Illumination. London: World of Festival Trust.

[13]. Lobo, A. G. (2013). Reader-Response Theory : A Path Towards Wolfgang Iser. Letras, 54(2013), $13-30$. Retrieved from https://www.revistas.una.ac.cr/index.php/letras /article/view/6955

[14]. Mujahidin, A. (2017). Analisis Simbolik Penggunaaaan Ayat-ayat Al-Qur an Sebagai Jimat Dalam Kehidupapan Masyarakat Ponorogo. Kalam Jurnal Studi Agama Dan Pemikiran Islam, 10(1), 43. https://doi.org/10.24042/klm.v10i1.159

[15]. Mujahidin, M. F. (2016). Pemikiran Kaligrafi Arab di Indonesia. Center of Middle Eastern Studies Jurnal Studi Timur Tengah, 9(2), 179-188. https://doi.org/https://jurnal.uns.ac.id/ cmes

[16]. Nuralia, L. (2017). Kaligrafi Islam Pada Dinding Masjid Kuna Cikoneng Anyer-Banten: Kajian Arti Dan Fungsi. Berkala Arkeologi, 37(1), 85-100. https://doi.org/10.30883/jba.v37i1.82

[17]. Raden, A. Z. M., Andrijanto, M. S., \& Sukarwo, W. (2019). Kaligrafi Arab Pada Jimat Dalam Perspektif Seni, Magi, dan Religi. Calls (Journal of Culture, Arts, Literature, and Linguistics), 5(1), 1-12. https://doi.org/http://dx.doi.org/10.30872/calls.v5i1.1717

[18]. Rahman, M. (2018). Resepsi terhadap Ayat Al-Kursī dalam Literatur Keislaman. Maghza: Jurnal Ilmu AlQur'an Dan Tafsir, 3(2), 134-147. https://doi.org/10.24090/maghza. v3i2.2127

[19]. Rispul. (2012). Kaligrafi Arab Sebagai Karya Seni. Tsaqafa Jurnal Kajian Seni Budaya Islam, 1(1), 918. Retrieved from http://eprints.uad.ac.id/1486/3/02-tsaqafa-Rispul-kaligrafi-arab-sebagai-seni.pdf

[20]. Santoso, H. (2015). Proses Pembuatan Kuningan Dari Logam. Retrieved November 9, 2020, from Kompasiana: Beyond Blogging hebsite: https://www.kompasiana.com/ hermansantoso/55099149813311490eb1e1cd/proses-pembuatan-kuningan-dari-logam

[21]. Shi, Y. (2013). Review of Wolfgang Iser and His Reception Theory. Theory and Practice in Language Studies, 3(6), 982-986. https://doi.org/10.4304/tpls.3.6.982-986

[22]. Sucitra, I. G. A. (2015). Transformasi Sinkretisma Indonesia dan Karya Seni Islam. Journal of Urban Society's Arts, 2(2), 89-103. https://doi.org/10.24821/jousa.v2i2.1446

[23]. Tesnawan, A. (2014). Penerapan Kaligrafi Arab Pada Hiasan Dinding. Yogyakarta. 